\title{
Cellular infiltrate of the jejunum after re-introduction of dietary gluten in children with treated coeliac disease
}

\author{
M. LANCASTER-SMITH, SUSAN PACKER, PARVEEN J. KUMAR, AND J. T. \\ HARRIES
}

From the Department of Gastroenterology, The Hospital for Sick Children, Great Ormond Street, London WC1, the Department of Gastroenterology, St. Bartholomew's Hospital, London EC1, and the Gastroenterology Unit, Queen Mary's Hospital, Sidcup, Kent

SYNOPSIS Jejunal lamina propria plasma cells and eosinophils and intraepithelial lymphocytes were raised in coeliac children on gluten-containing diets, but only intraepithelial lymphocytes were increased in patients on gluten-free diets. In contrast, lamina propria lymphocytes were reduced in children with coeliac disease on gluten-containing diets but were normal in patients on gluten-free diets. In children with coeliac disease who were studied serially, lamina propria plasma cells and eosinophils and intraepithelial lymphocytes increased, and lamina propria lymphocytes decreased, within three months of the reintroduction of gluten to the diet. These observations are essentially similar to those made in the adult form of the disease and suggest that more than one type of immunological reaction is involved in the pathogenesis of the jejunal lesion.

Immunohistochemical (Douglas et al, 1970; Pettingale, 1971; Salvilahti, 1972; Shiner and Ballard, 1972; Doe et al, 1974) and ultrastructural (Shiner, 1973) studies suggest that humoral immune reactions play a part in the pathogenesis of the jejunal lesion of coeliac disease. Other observations, however, suggest that cell-mediated mechanisms involving either thymus-dependent (Ferguson, 1974) or nonimmune lymphocytes (Ezeoke et al, 1974) are important. This local immune activity is reflected in an excess of intraepithelial lymphocytes (Ferguson and Murray, 1971) and abnormal numbers of lamina propria cells in the jejunum (Holmes et al, 1974; Montgomery and Shearer, 1974). Alterations in plasma and lymphocyte numbers might implicate humoral or cell-mediated mechanisms respectively, while an increase in granulocytes could support existing evidence that immune complexes are involved. The aim of this study, therefore, was to gain further information about these cell classes in the hope of clarifying the pathogenesis of the small bowel lesion of childhood coeliac disease and to see if this differed from that found in adult patients.

\section{Patients and methods}

In the group of patients studied a past diagnosis of

Received for publication 10 December 1975 coeliac disease had been based on suggestive clinical and biochemical evidence but without jejunal biopsy confirmation. The children had been managed on a gluten-free diet and the majority were continuing on this regime at the time of study. Because of this unsatisfactory basis for the original diagnosis and in order to advise on a rational future treatment it was necessary to confirm or exclude the diagnosis of coeliac disease by jejunal biopsy. This in most instances required appraisal of jejunal morphology after reintroduction of gluten to the diet.

\section{PATIENTS}

Twenty-two children who had previously been diagnosed tenuously as having coeliac disease without histological confirmation between the ages of 0.5 and 5 years, mean 2 years, were included in the study at which time the mean age was 11.5 years, range 5-16.5 years. A thorough assessment of the diet was made in all patients by the same dietitian. Sixteen had been on a gluten-free diet from 1.5 to 13 years, mean 6.9 years, and six admitted to consuming varying amounts of gluten immediately before this study for three months to 12 years, mean 5.3 years. Jejunal biopsies were obtained at the beginning of the investigation. If the initial biopsy showed villous atrophy the diagnosis of coeliac disease was accepted. If, in contrast, the first biopsy 
was normal, the patient was instructed to take a diet containing at least $10 \mathrm{~g}$ of gluten as natural wheat protein per day for a period of three months, after which the patient was investigated again. Thus in 16 children biopsies were obtained while on gluten-free and, after three months, on gluten-containing diets.

\section{METHODS}

Jejunal biopsies were obtained by Crosby Capsule in fasting subjects from the duodenojejunal flexure under fluoroscopic control. Tissue was processed routinely and sections 5 microns thick were cut and stained with haematoxylin and eosin. Lamina propria cells were counted at a magnification of 1000 over an area of $0.25 \mathrm{~mm}^{2}$ from representative zones between the muscularis mucosae and epithelium, results being expressed as cells per square metre (Savilahti, 1972). Particular note was made of the numbers of plasma cells, lymphocytes, eosinophils, and neutrophils. Intraepithelial lymphocytes were also counted, results being expressed as lymphocytes per 100 epithelial cells (Ferguson and Murray, 1971). Villous heights were measured using a micrometer eye piece (Stewart et al, 1967).

The Student $t$ test was used for statistical analysis.

\section{Results}

JEJUNAL MORPHOLOGY

Of the six subjects who were on a gluten-containing diet, two had villous atrophy (villous heights 0 and 120 microns) and have coeliac disease, while the $\frac{\text { - }}{-}$ remaining four had a normal villous structure $\Rightarrow$ (villous height, mean \pm standard error (SE) $413 \pm \stackrel{\oplus}{\rightarrow}$ 33.1 microns), excluding the diagnosis of coeliac? disease. Of the 16 on an alleged gluten-free diet, $13 \frac{\bar{\sigma}}{\bar{\omega}}$ had a normal initial biopsy (villous heights, mean $\frac{\widehat{\Phi}}{\widehat{\sigma}}$ $\pm \mathrm{SE} 387 \pm 15.7$ microns). After three months on a gluten-containing diet 10 of these had a significant mucosal lesion (villous heights, mean \pm SE $119 \pm \overrightarrow{0}$ 28.5). Three, however, remained normal (villous heights, mean \pm SE $444 \pm 23.5$ ) and have continued $\vec{\omega}$ to show no evidence of coeliac disease after 24 ? months on a substantial daily intake of gluten. Theo other three patients with abnormal jejunal morpho- 0 logy (villous heights, mean $\pm \mathrm{SE} 212 \pm 65 \cdot 7$. microns) while on alleged gluten-free diets which on $\mathcal{O}_{\infty}$ further investigation were found to contain small $v$ amounts of gluten showed increased morphological ? deterioration after three months on a $10 \mathrm{~g}$ gluten-

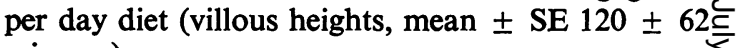
microns).

Therefore, of the 22 subjects studied, 15 have $\vec{\theta}$ proven coeliac disease based on the jejunal mucosalo response to gluten. The remaining seven had a normalס mucosa and showed no evidence of coeliac disease even after a substantial intake of gluten ranging $\bar{\partial}$ from 24 months to 12 years. The cause of these subjects' past gastrointestinal symptoms is not $\stackrel{\square}{\Phi}$ known but they clearly do not have coeliac disease. $\stackrel{2}{\vec{P}}$

\begin{tabular}{|c|c|c|c|c|c|}
\hline \multirow[t]{2}{*}{ Subjects } & \multirow[t]{2}{*}{ No. } & \multicolumn{3}{|c|}{ Lamina propria ${ }^{1}$} & \multirow{2}{*}{$\begin{array}{l}\text { Intraepithelial } \\
\text { lymphocytes }\end{array}$} \\
\hline & & Plasma cells & Lymphocytes & Eosinophils & \\
\hline \multicolumn{6}{|l|}{ Coeliac } \\
\hline $\begin{array}{l}\text { No gluten } \\
\text { Gluten }\end{array}$ & $\begin{array}{l}13 \\
13\end{array}$ & $\begin{array}{l}3019 \pm 363 \\
5536 \pm 359\end{array}$ & $\begin{array}{r}1562 \pm 158 \\
947 \pm 92\end{array}$ & $\begin{array}{l}379 \pm 75 \\
797 \pm 105\end{array}$ & $\begin{array}{l}39 \pm 3 \cdot 5 \\
59 \pm 1 \cdot 5\end{array}$ \\
\hline \multicolumn{6}{|l|}{ Controls } \\
\hline $\begin{array}{l}\text { No gluten } \\
\text { Gluten }\end{array}$ & $\begin{array}{l}3 \\
3\end{array}$ & $\begin{array}{l}2185 \pm 128 \\
2376 \pm 565\end{array}$ & $\begin{array}{l}1476 \pm 115 \\
1423 \pm 130\end{array}$ & $\begin{array}{l}337 \pm 53 \\
435 \pm 105\end{array}$ & $\begin{array}{l}30 \pm 1.0 \\
31 \pm 0.6\end{array}$ \\
\hline $\begin{array}{c}\text { Controls } \\
\text { (Total) }\end{array}$ & 10 & $2531 \pm 203$ & $1382 \pm 55$ & $320 \pm 54$ & $30 \pm 2 \cdot 6$ \\
\hline
\end{tabular}

Table I Jejunal infiltrate in coeliac children and controls before and after reintroduction of dietary gluten

Means \pm SE

'Lamina propria cells expressed as cells per $\mathbf{~ m m}^{2}$

2Intraepithelial lymphocytes expressed as lymphocytes per 100 epithelial cells.

\begin{tabular}{|c|c|c|c|c|c|c|}
\hline & \multirow[t]{2}{*}{ No. } & \multirow{2}{*}{$\begin{array}{l}\text { Villous } \\
\text { heights }\end{array}$} & \multicolumn{3}{|c|}{ Lamina propria ${ }^{1}$} & \multirow{2}{*}{$\begin{array}{l}\text { Intraepithelial } \\
\text { lymphocytes }^{2}\end{array}$} \\
\hline & & & Plasma cells & Lymphocytes & Eosinophils & \\
\hline $\begin{array}{l}\text { Coeliac villous atrophy } \\
\text { Coeliac normal villous }\end{array}$ & 18 & $128 \pm 23$ & $5286 \pm 298$ & $985 \pm 88$ & $750 \pm 83$ & $59 \pm 2 \cdot 3$ \\
\hline $\begin{array}{l}\text { morphology } \\
\text { Controls }\end{array}$ & $\begin{array}{l}10 \\
10\end{array}$ & $\begin{array}{l}379 \pm 18 \\
423 \pm 17\end{array}$ & $\begin{array}{l}2829 \pm 166 \\
2531 \pm 203\end{array}$ & $\begin{array}{l}1636 \pm 98 \\
1382 \pm 55\end{array}$ & $\begin{array}{l}263 \pm 47 \\
320 \pm 54\end{array}$ & $\begin{array}{l}35 \pm 2 \cdot 9 \\
30 \pm 2 \cdot 6\end{array}$ \\
\hline
\end{tabular}

Table II Relationship of jeujnal infitrate to villous structure

1,2 See footnotes to table I. 
Fig 1
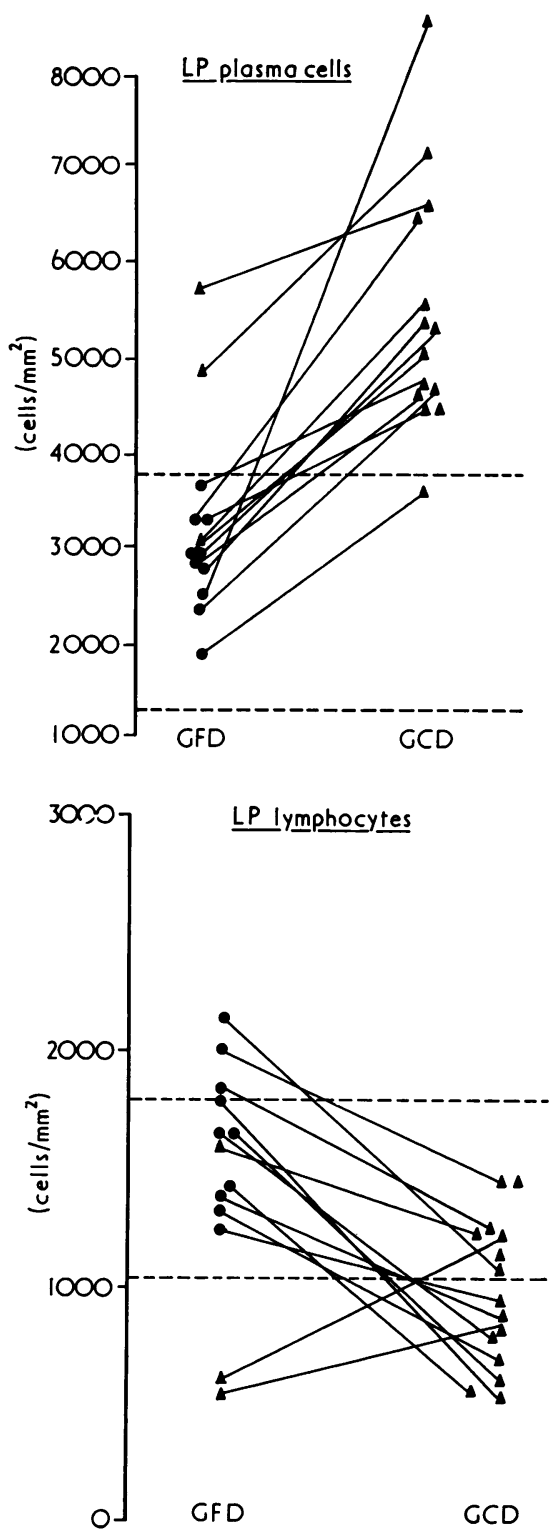

Fig 2

In view of their completely normal jejunal morphology, subsequent good health, and, in particular, the absence of gastrointestinal disturbance for many years before this study, it was considered reasonable to accept them as controls.

LAMINA PROPRIA CELLS (see tables I and II and figs 1-3)

Plasma cells

Numbers of these cells in coeliac patients on a gluten-free diet did not differ significantly from

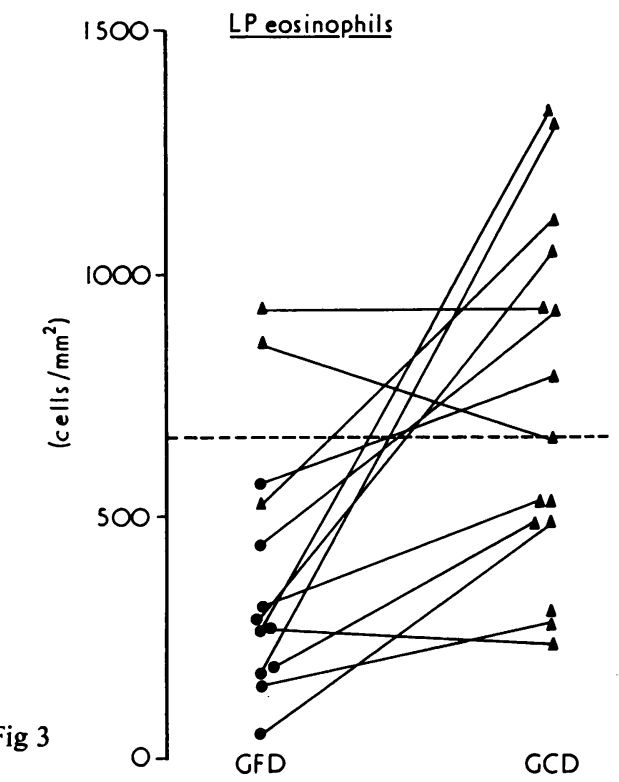

Figs 1-3 Cellular infiltrate of the lamina propria $(L P)$ in children with coeliac disease on gluten-free (GFD) and gluten-containing (GCD) diets. Cells expressed as numbers per square millimetre.

controls. In contrast, they were raised in patients on gluten-containing diets compared to controls ( $P<$ 0.002 ). In the coeliacs studied serially, there was a significant increase in plasma cells after three months on a gluten-containing diet $(\mathrm{P}<0.002)$. Coeliac biopsies with normal villous morphology and controls had the same numbers of plasma cells but both contained fewer than coeliac biopsies with villous atrophy $(\mathrm{P}<0.002 ; \mathrm{P}<0.002)$.

\section{Lymphocytes}

Numbers of lymphocytes in coeliac patients on a gluten-free diet did not differ significantly from controls. In contrast, these cells in coeliac patients on gluten-containing diets were decreased compared to controls $(P<0.01)$. In the coeliac patients studied serially there was a significant fall in numbers after three months on a gluten-containing diet $(\mathbf{P}<0.01)$. Coeliac biopsies with normal villous morphology and controls had the same numbers of lymphocytes but both contained more than coeliac biopsies with villous atrophy $(\mathrm{P}<0.002$; $\mathrm{P}<0.05)$.

\section{Eosinophils}

Numbers of eosinophils in coeliac patients on a gluten-free diet did not differ from controls. In contrast, they were increased in coeliac patients on gluten-containing diets compared with controls 


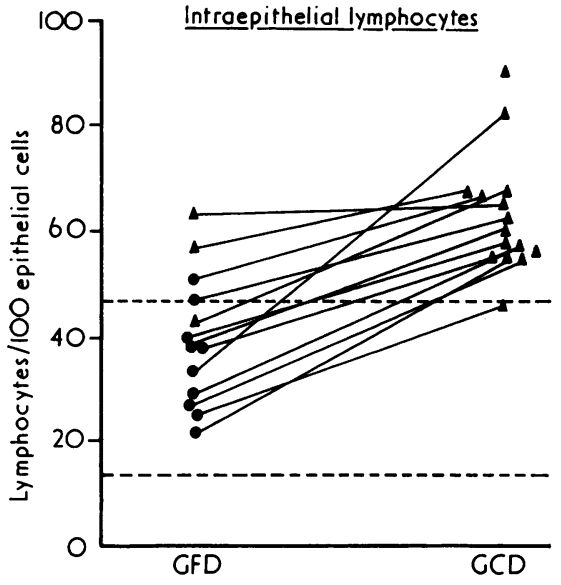

Fig 4 Intraepithelial lymphocytes expressed as lymphocytes per 100 epithelial cells: - normal villous morphology; $\Delta$ villous atrophy. Horizontal lines represent 2 standard deviations above and below the mean.

$(P<0.01)$. In coeliac patients studied serially there was an increase after three months on a glutencontaining diet $(P<0.01)$. Coeliac biopsies with normal villous structure and controls had the same number of eosinophils but both had fewer than coeliac biopsies with villous atrophy $(P<0.01$; $\mathrm{P}<0.01$ ).

\section{Neutrophils}

Small numbers of neutrophils were seen in seven of the 15 biopsies from coeliac patients on glutencontaining diets. They were not found in biopsies from patients on gluten-free diets or controls.

INTRAEPITHELIAL LYMPHOCYTES (see tables I and II and fig 4)

These cells were increased in coeliac patients on both gluten-containing and gluten-free diets compared with controls $(P<0.002 ; P<0.05)$. In patients studied serially there was a significant increase after three months on a gluten-containing diet ( $<<0.002)$. Coeliac biopsies with normal villous morphology and controls had the same numbers of intraepithelial lymphocytes but both had fewer than coeliac biopsies with villous atrophy $(P<0.002 ; P<0.002)$.

In the three serially studied subjects who had normal villous morphology on both gluten-free (villous heights, mean \pm SE $415 \pm 32$ microns) and gluten-containing diets (villous heights, mean $\pm \mathrm{SE}$ $444 \pm 23.5$ microns) there was no change in lamina propria or intraepithelial cell numbers.

\section{Discussion}

A possible explanation for the reduction in lamina propria lymphocytes after the reintroduction ob dietary gluten in this study as noted in untreated. adult patients (Holmes et al, 1974) is that under the antigenic stimulus of gluten, sensitized lymphocytes? transform into plasma cells (Roitt, 1971). Such를 transformation would lead to the associated increase in plasma cells found in our children and previousl $\mathbb{R}_{\mathscr{Q}}^{\mathbb{R}}$ studied adults (Holmes et al, 1974; Montgomery and్ Shearer, 1974; Lancaster-Smith et al, 1975).

An alternative reason for the depletion of lamina propria lymphocytes would be increased migration of these cells into the epithelial cell layer, thus giving rise to the excess of intraepithelial lymphocyte 8 found in the currently studied children and in adulto coeliac disease (Ferguson and Murray, 1971; Holmes et al, 1974; Montgomery and Shearer, 1974; Lancaster-Smith et al, 1975). The increased loss of lymphocytes from the epithelium into the gut lumen? in untreated coeliac patients (Weetman et al, 1974) would support this hypothesis.

The increase in eosinophils confirms by quantitative methods the impression that these cells increase inco coeliac children challenged with gluten (Shiner andos Ballard, 1972). In adults, similar observations have been made (Pettingale, 1971; Lancaster-Smith et al, 1975) although other workers have not found a significant jejunal eosinophilia (Montgomery ando Shearer, 1974; Holmes et al, 1974). The smallo̊ numbers of neutrophils in some coeliac children in this study after gluten ingestion agrees with othero results in children (Shiner and Ballard, 1972) and ${ }^{3}$ adults (Doe et al, 1974; Lancaster-Smith et al, 1975) Both eosinophil and neutrophil granulocytes are attracted by immune complexes (Kay, 1970). Ouro results might thus indirectly support the opinionthat immune-complexes are formed in the jejunum at some stage in the pathogenesis of the mucosalo lesion (Shiner and Ballard, 1972; Doe et al, 1974).

The effect of gluten on the jejunal inflammatoryo infiltrate in childhood coeliac disease is therefore essentially the same as in adult patients (Holmeso et al, 1974; Montgomery and Shearer, 1974; Lancaster-Smith et al, 1975). In children a prolonged.o gluten-free diet results in a virtually normal infiltrate $N$ of the jejunum in association with a return to normal villous structure. This contrasts with adult patients $\sigma$ on long-term treatment in whom abnormalities of the infiltrate remain in the majority of cases despite $\frac{\bar{\Phi}}{\bar{\tau}}$ only minor abnormalities of villous morphology $\stackrel{9}{+}$ (Holmes et al, 1974; Lancaster-Smith et al, 1975). T One explanation for this would be that adult patients ${ }_{0}^{\circ}$ adhere less strictly than children to a gluten-free $\stackrel{\mathbb{Q}}{\stackrel{D}{0}}$ diet. Alternatively, it could be that in adults with $\vec{\nabla}$ prolonged exposure to gluten before treatment the $\frac{a}{\sigma}$ mucosa is more severely damaged and thus less capable of returning completely to normal. Neverthe- 
less it is clear that in both childhood and adult forms of coeliac disease many cell types are involved in the inflammatory response to gluten, and this is compatible with current knowledge and opinion (Lancet, 1974) that more than one immunological mechanism may be responsible for the jejunal lesion of coeliac disease.

SP and JTH gratefully acknowledge the support of The Wellcome Trust; SP also acknowledges the support of The British Council. We thank Dr M. L. Clark for his help and The Action Research for the Crippled Child which assisted in financing this project. We also thank Professor Soothill for estimating the serum immunoglobulin levels. ML-S was on an elective research period from The London Hospital.

\section{References}

Doe, W. F., Henry, K., and Booth, C. C. (1974). Complement in coeliac disease. In Coeliac Disease: Proceedings of the 2nd International Coeliac Symposium, edited by J. M. Hekkens and A. S. Pena, pp. 176-188. Stenfert Kroese, Leyden.

Douglas, A. P., Crabbé, P. A., and Hobbs, J. R. (1970). Immunochemical studies of the serum, intestinal secretions and intestinal mucosa in patients with adult celiac disease and other forms of the celiac syndrome. Gastroenterology, 59, 414-425.

Ezeoke, A., Ferguson, N., Fakhri, O., Hekkens, T. J. M., and Hobbs, J. R. (1974). Antibodies in the sera of coeliac patients that can coopt $\mathrm{K}$ cells to attack gluten labelled targets. In Coeliac Disease: Proceedings of the 2nd International Coeliac Symposium, edited by J. M. Hekkens and A. S. Pena, pp. 176-188. Stenfert Kroese, Leyden.

Ferguson, A. (1974). Lymphocytes in coeliac disease. In
Coeliac Disease: Proceedings of the 2nd International Coeliac Symposium, edited by J. M. Kekkens and A. S. Pena, pp. 265-276. Stenfert Kroese, Leyden.

Ferguson, A. and Murray, D. (1971). Quantitation of intraepithelial lymphocytes in human jejunum. Gut, 12, 988-994.

Holmes, G. K. T., Asquith, P., Stokes, P. L., and Cooke, W. T. (1974). Cellular infiltrate of jejunal biopsies in adult coeliac disease in relation to gluten withdrawal. Gut, 15, 278-283.

Kay, A. B. (1970). Studies on eosinophil leucocyte migration. 2. Factors specifically chemotactic for eosinophils and neutrophils generated from guinea-pig serum by antigenantibody complexes. Clin. exp. Immunol., 7, 723-737.

Lancaster-Smith, M., Kumar, P. J., and Dawson, A. M. (1975). The cellular infiltrate of the jejunum in adult coeliac disease and dermatitis herpetiformis following the reintroduction of dietary gluten. Gut, 16, 683-688.

Lancet (1974). Editorial. The coeliac philosophy. Lancet, 2, 501-502.

Montgomery, R. D., and Shearer, A. C. I. (1974). The cell population of the upper jejunal mucosa in tropical sprue and postinfective malabsorption. Gut, 15, 387-391.

Pettingale, K. (1971). Immunoglobulin-containing cells in the coeliac syndrome. Gut, 12, 291-296.

Roitt, I. M. (1971). The synthesis of antibody. In Essential Immunology, pp. 35-62. Blackwell, Oxford.

Savilahti, E. (1972). Intestinal immunoglobulins in children with coeliac disease. Gut, 13, 958-964.

Shiner, M. (1973). Ultrastructural changes suggestive of immune reactions in the jejunal mucosa of coeliac children following gluten challenge. Gut, 14, 1-12.

Shiner, M. and Ballard, J. (1972). Antigen-antibody reactions in jejunal mucosa in childhood coeliac disease after gluten challenge. Lancet, 1, 1202-1205.

Stewart, J. S., Pollock, D. J., Hoffbrand, A. V., Mollin, D. L., and Booth, C. C. (1967). A study of proximal and distal intestinal structure and absorptive function in idiopathic steatorrhoea. Quart. J. Med., 36, 425-444.

Weetman, A. P., Haggith, J., and Douglas, A. P. (1974). Enteric loss of lymphocytes in coeliac disease and Crohn's disease (Abstract). Gut, 15, 823. 